\title{
Timeline
}

\section{Relevant Events and Historical Developments}

c. 1500 BCE The Rig Veda is composed

c. 600-400 BCE The Upanishads are composed

c. 500 BCE The Shrauta-sutras are composed

c. 486 BCE Gautama Shakyamuni, the Buddha, dies

327-325 BCE Alexander the Great invades northwest South

Asia

c. 324 BCE Chandragupta founds the Mauryan dynasty

c. 300 BCE-30o CE Grihya-sutras, some dharma-shastras, and the Mahabharata are composed

c. 265-232 BCE Ashoka reigns

c. 250 BCE The Third Buddhist Council takes place at Pataliputra

c. 200 BCE-200 CE More dharma-shastras and the Ramayana are composed

c. 185 BCE The Mauryan dynasty ends

c. $185 \mathrm{BCE}-73 \mathrm{BCE}$ The Shunga dynasty is in power

c. 166 BCE-78 CE Greeks, Scythians, Bactrians, and Parthians enter India

c. 78-144 CE The Kushanas are in power 
c. 100 CE "Manu" composes his dharma-shastra

c. 112-144 CE Kanishka rules

c. 150 CE Rudradaman publishes the first Sanskrit inscription at Junagadh

c. 200 CE Kautilya composes the Arthashastra

c. 300 CE Vatsyayana Mallanaga composes the Kamasutra

c. 320-550 CE The Gupta Empire is in power

c. 750-1500 Medieval Puranas are composed

c. 788-820 The philosopher Shankara lives

1021 The Ghaznavid (Turkish) Muslim Empire is

established

1526 Babur founds the Mughal Empire

1556-1605 Akbar rules

1600 Queen Elizabeth I charters the British East India

Company

1828 Rammohun Roy founds the Brahmo Samaj

1858 The British Viceroy officially replaces Mughal rule

[and the East India Company]

1947 Indian Independence is achieved; Partition takes place

2014 The Bharatiya Janata Party and Narenda Modi are elected 
Against Dharma 
This page intentionally left blank 